\title{
Suitable Soil Conditions for Tomato Cultivation under an Organic Farming System
}

\author{
Dinesh Adhikari, Yuya Kobashi, Takamitsu Kai, Taiki Kawagoe, Kenzo Kubota, \\ Kiwako S. Araki, Motoki Kubo
}

Department of Biotechnology, Faculty of Life Sciences, Ritsumeikan University, Kusatsu, Japan

Email: kubo@sk.ritsumei.ac.jp

How to cite this paper: Adhikari, D., Kobashi, Y., Kai, T., Kawagoe, T., Kubota, K., Araki, K.S. and Kubo, M. (2018) Suitable Soil Conditions for Tomato Cultivation under an Organic Farming System. Journal of Agricultural Chemistry and Environment, 7, 117-132.

https://doi.org/10.4236/jacen.2018.73011

Received: May 28, 2018

Accepted: July 29, 2018

Published: August 1, 2018

Copyright $\odot 2018$ by authors and Scientific Research Publishing Inc. This work is licensed under the Creative Commons Attribution International License (CC BY 4.0).

http://creativecommons.org/licenses/by/4.0/

\begin{abstract}
This study was conducted to determine the suitable soil conditions for tomato cultivation under an organic farming system. Tomatoes were cultivated in chemically and organically fertilized experimental fields from 2013 to 2015 in Moriyama City, Shiga prefecture, Japan. Organically and chemically fertilized soils had different total carbon (TC) and total nitrogen (TN) contents, and different carbon-to-nitrogen ratios ( $\mathrm{C} / \mathrm{N}$ ratios). The tomato yields varied from 1290 to $5960 \mathrm{~kg} / 0.1 \mathrm{ha}$ in the organically fertilized fields. The organic soil conditions for the highest tomato yield showed a TC content of $\sim 33,000$ $\mathrm{mg} / \mathrm{kg}$, TN content of $\sim 1600 \mathrm{mg} / \mathrm{kg}$, and a C/N ratio of $\sim 21$. The yield was reproducible in the organic fields under similar values of TC, TN, and $\mathrm{C} / \mathrm{N}$ ratio in the soil. Significantly higher nitrogen and phosphorus circulation activities were observed in the high-yielding fields. Appropriate control of TC, $\mathrm{TN}$, and $\mathrm{C} / \mathrm{N}$ ratio is necessary for the enhancement of both microbial activity and tomato yield. Values of the important tomato quality parameters (lycopene, glutamic acid, and acid content) were also increased in the highyielding tomato fields. We therefore suggest that a suitable soil condition for improving both the yield and quality of tomatoes in an organic farming system is TC of $30,000-36,000 \mathrm{mg} / \mathrm{kg}$, TN of $1600-1900 \mathrm{mg} / \mathrm{kg}$, and a C/N ratio of $18-21$.
\end{abstract}

\section{Keywords}

Tomato, Bacterial Biomass, Nitrogen Circulation Activity, Phosphorus Circulation Activity, SOFIX

\section{Introduction}

Tomato (Solanum lycopersicum L.) is one of the most important vegetables glo- 
bally and is cultivated in temperate to tropical regions. Recent world production of fresh tomato fruits was 165 million tons with a value of about 60 billion US dollars in 2013 [1].

Tomato fruits contain protein, fat, carbohydrate, minerals (such as calcium, phosphorus, and iron), carotene, thiamine, nicotinic acid, riboflavin, and ascorbic acid [2]. Tomato is also an important source for vitamins A and C, carotenoids, and lycopene [3]. Lycopene helps to reduce cancer risks [4] and protects the skin from ultraviolet radiation [5]. Carotenoids are useful against breast cancer and prostate cancer [6]. Tomato is ranked among the top five vegetables in terms of antioxidant activity [7].

Tomatoes are cultivated mainly by conventional methods using chemical fertilizers and agrochemicals. A recent report showed that only $1 \%$ of agricultural fields in the world are cultivated under organic farming systems [8]. Although the yield is relatively stable in conventional farming systems, excessive use of chemical fertilizers and agrochemicals can cause severe environmental, socio-economic, and human health problems. As a result, consumer awareness towards organic foods has been increasing recently.

Organic cultivation methods cause relatively lower environmental damage if compared with conventional farming and the organic crop product is considered tasty and healthy [9]. Studies on tomato have also shown that antioxidants, flavonoids, sugar, and vitamin $\mathrm{C}$ are generally higher in organically grown fruits than conventionally grown fruits [10] [11] [12]. However, the yield is more unstable and/or lower in organic farming systems than conventional systems [11] [13] [14] [15]. Therefore, an alternative organic agricultural system is required to ensure high yield and quality of agricultural products. In addition, the cultivation method must be efficient, reliable, reproducible, and simple.

Soil microorganisms play several beneficial roles such as decomposing organic materials, releasing nutrients to plants, and bioremediation of pesticide polluted soils [16] [17] [18]. Therefore, soil microorganisms are considered key players in maintaining soil fertility. A large and active microorganism community is needed for efficient nutrient cycling and steady supply of nutrients to the plants. Improving soil environment by controlling the organic matter level and nutrient ratio in the soil is important for soil microorganisms [13] [19].

In our previous study, we developed a soil fertility index, SOFIX, for the evaluation of soil fertility [20]. Analysis of the SOFIX data from several agricultural fields clearly showed that the number and activities of microorganisms can be significantly enhanced by controlling total carbon (TC) and total nitrogen (TN) contents, and carbon-to-nitrogen ratios (C/N ratios) at $\geq 25,000 \mathrm{mg} / \mathrm{kg}, \geq 2500$ $\mathrm{mg} / \mathrm{kg}$, and $10-25$, respectively. However, the relationship between microbial activities and plant growth remains unknown. The objective of this study was to determine suitable soil conditions for improving the yield and quality of tomato under an organic farming system by enhancing the number and activities of soil microorganisms. 


\section{Materials and Methods}

\subsection{The Study Site}

This study was carried out in agricultural fields located in Moriyama, Shiga prefecture, Japan $\left(35^{\circ} 5^{\prime} 33.85^{\prime} \mathrm{N}, 135^{\circ} 58^{\prime} 28.57^{\prime \prime} \mathrm{E}\right)$. The experiments were performed in three consecutive years from 2013 to 2015 to confirm the reproducibility under seasonal fluctuation. Moriyama has a humid temperate climate, where July is the warmest month and January is the coolest. Weather data of the nearest meteorological station (Hikone, Shiga, Japan) from the experimental field during the tomato growth period is shown in Figure 1. The initial physico-chemical properties of soil in the experimental field are shown in Table 1.

\subsection{Cultivation of Tomato in the Fields under Chemical and Organic Farming Systems}

In our previous study, we found that microorganisms and nutrient cycling activities in the soil are highly enhanced at $\mathrm{TC} \geq 25,000 \mathrm{mg} / \mathrm{kg}$ and $\mathrm{C} / \mathrm{N}$ ratios from 10 to 25 in soil [20]. In this study, the soil conditions suitable for enhancing the activity of microorganisms were examined for tomato cultivation. Seven organic and two chemical experimental conditions were prepared by using 3 field compartments in 2013 to 2015 (Table 2). Organic experimental fields were prepared with TC from 27,500 to 58,000 mg/kg, TN from 1000 to $4300 \mathrm{mg} / \mathrm{kg}$, and C/N ratio from 13 to 30 (Fields A and B in 2013, Fields C and D in 2014, and Fields $\mathrm{G}, \mathrm{H}$, and I in 2015). To provide different $\mathrm{TC}, \mathrm{TN}$, and $\mathrm{C} / \mathrm{N}$ ratio in the organic fields, cow manure, chicken manure, and soybean meal were used. The nutrient contents in the organic fertilizers are shown in Table 3.

In 2013 and 2014, a control experiment was simultaneously carried out using the chemical fertilization plan recommended for tomato by Shiga prefecture, Japan (200:180:250 kg N: $\mathrm{P}_{2} \mathrm{O}_{5}: \mathrm{K}_{2} \mathrm{O}$ per ha) (Field E in 2013 and Field $\mathrm{F}$ in 2014). A half dose of $\mathrm{N}$ and full doses of $\mathrm{P}$ and $\mathrm{K}$ were applied on the day of transplanting and the remaining half dose of $\mathrm{N}$ was top dressed after one month. Following chemical fertilizers were used: ammonium sulfate $(21 \% \mathrm{~N})$, single super phosphate $\left(17.5 \% \mathrm{P}_{2} \mathrm{O}_{5}\right)$, and potassium sulfate $\left(50 \% \mathrm{~K}_{2} \mathrm{O}\right)$. The differences in $\mathrm{TC}$, $\mathrm{TN}$, and $\mathrm{C} / \mathrm{N}$ ratio between the two chemical fields was due to the seasonal effect.

Each field was $24 \mathrm{~m}^{2}(6 \mathrm{~m} \times 4 \mathrm{~m})$ and had 6 plant rows with 60 plants (10 plants per row). Fields were $1 \mathrm{~m}$ apart to prevent interaction between the treatments. One-month old seedlings of tomato (cv. Momotaro) were transplanted in May. The seedlings were purchased from TAKII \& Co. Ltd., Kyoto, Japan. No pesticides were used in both chemical and organic fields. Black plastic mulch was used to control weeds and conserve the soil moisture.

\subsection{Harvesting and Yield Measurement}

Tomatoes were harvested once the fruits turned light red. In all years, harvesting began at the end of June and lasted until the beginning of August. The fresh 


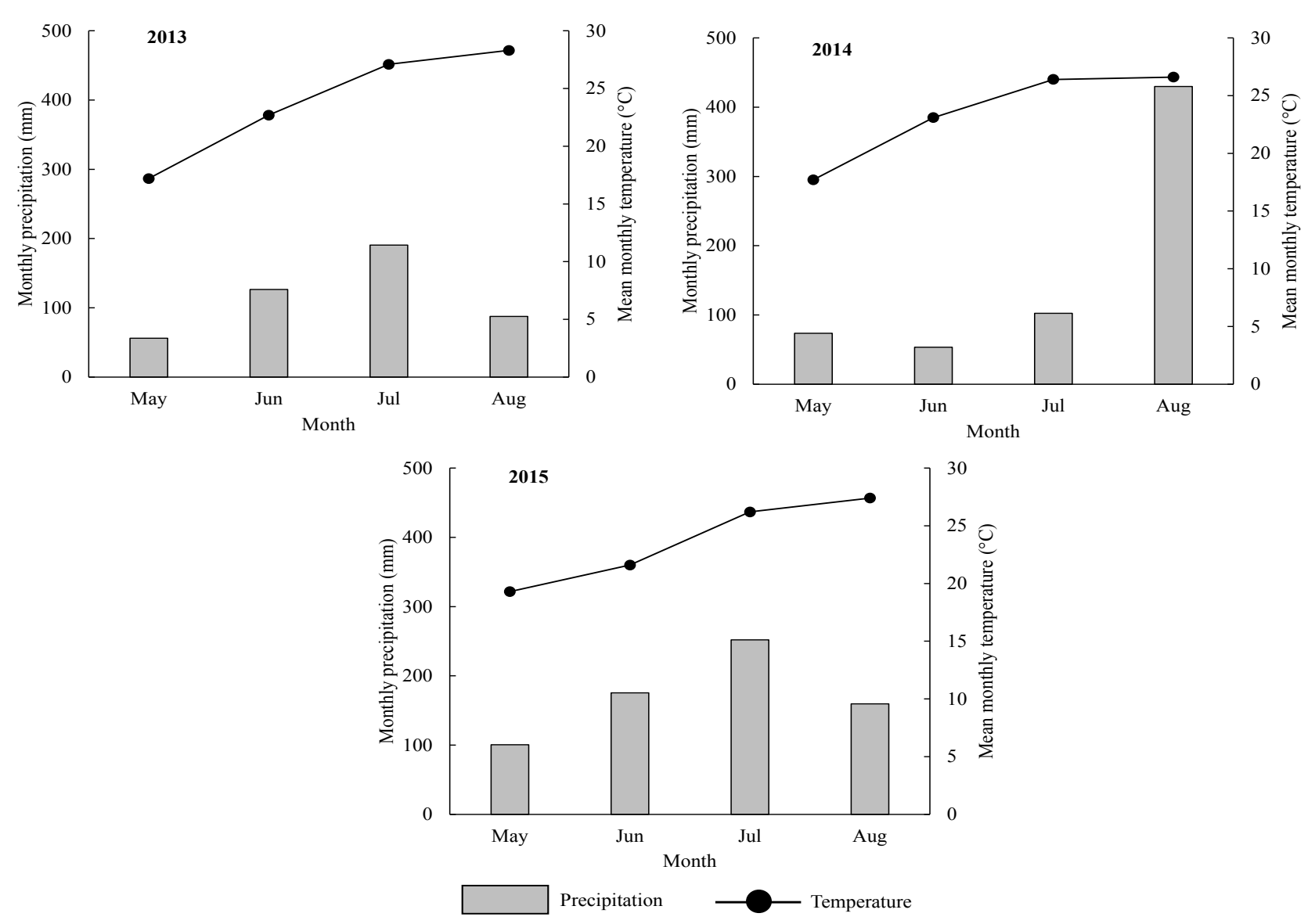

Figure 1. Weather data of the nearest meteorological station from the experimental field (Hikone, Shiga) during tomato growing months in 2013 to 2015. Precipitation $(\mathrm{mm})(\square)$ and mean monthly temperature $\left({ }^{\circ} \mathrm{C}\right)(\rightarrow-)$ from May to August are shown. (Source: Japan Meteorological Agency (http://www.data.jma.go.jp)).

Table 1. Initial physico-chemical properties of soil of the experimental field.

\begin{tabular}{cc}
\hline Soil property & Value or type \\
\hline Texture & Sandy loam \\
$\mathrm{pH}(1: 2.5$; soil-to-water, w/v) & $5.5( \pm 0.10)$ \\
Bulk density $(\mathrm{dry})\left(\mathrm{g} / \mathrm{cm}^{3}\right)$ & $1.53( \pm 0.04)$ \\
$\mathrm{TC}(\mathrm{mg} / \mathrm{kg})$ & $20,000( \pm 1730)$ \\
$\mathrm{TN}(\mathrm{mg} / \mathrm{kg})$ & $900( \pm 130)$ \\
$\mathrm{C} / \mathrm{N}$ ratio & $22( \pm 4)$ \\
$\mathrm{TP}(\mathrm{mg} / \mathrm{kg})$ & $1090( \pm 66)$ \\
$\mathrm{TK}(\mathrm{mg} / \mathrm{kg})$ & $3330( \pm 210)$ \\
\hline
\end{tabular}

Value in parenthesis followed by \pm is standard deviation $(\mathrm{n}=3)$.

weight of the harvested tomato was recorded. On the last day, all remaining fruits were also picked for weighing.

\subsection{Analysis of Soil Properties}

Soil analysis was done using a composite sample taken from 5 randomly selected points in a field. The following soil properties were analyzed: TC, TN, total 
Table 2. Farming system and soil condition in this study.

\begin{tabular}{cccccc}
\hline Year & $\begin{array}{c}\text { Experimental } \\
\text { field }\end{array}$ & $\begin{array}{c}\text { Farming } \\
\text { system }\end{array}$ & TC $(\mathrm{mg} / \mathrm{kg})$ & TN $(\mathrm{mg} / \mathrm{kg})$ & C/N ratio \\
\hline 2013 & A & Organic & $57,000^{\mathrm{a}}( \pm 2650)$ & $2800^{\mathrm{b}}( \pm 170)$ & $20^{\mathrm{bc}}( \pm 2.1)$ \\
& B & Organic & $58,000^{\mathrm{a}}( \pm 2000)$ & $4300^{\mathrm{a}}( \pm 270)$ & $13^{\mathrm{d}}( \pm 0.4)$ \\
& C & Chemical & $20,000^{\mathrm{d}}( \pm 1730)$ & $900^{\mathrm{e}}( \pm 130)$ & $22^{\mathrm{b}}( \pm 3.2)$ \\
2014 & D & Organic & $27,500^{\mathrm{c}}( \pm 1320)$ & $1400^{\mathrm{d}}( \pm 100)$ & $20^{\mathrm{bc}}( \pm 0.6)$ \\
& E & Organic & $36,000^{\mathrm{b}}( \pm 1730)$ & $1900^{\mathrm{c}}( \pm 170)$ & $19^{\mathrm{bc}}( \pm 2.4)$ \\
& F & Chemical & $16,000^{\mathrm{d}}( \pm 1730)$ & $1000^{\mathrm{e}}( \pm 120)$ & $16^{\mathrm{cd}}( \pm 3.5)$ \\
& G & Organic & $31,000^{\mathrm{bc}}( \pm 2000)$ & $1000^{\mathrm{e}}( \pm 170)$ & $30^{\mathrm{a}}( \pm 4.2)$ \\
& H & Organic & $33,000^{\mathrm{bc}}( \pm 1730)$ & $1600^{\mathrm{cd}}( \pm 100)$ & $21^{\mathrm{bc}}( \pm 1.6)$ \\
& I & Organic & $30,000^{\mathrm{bc}}( \pm 1730)$ & $1700^{\mathrm{cd}}( \pm 87)$ & $18^{\mathrm{bc}}( \pm 1.9)$ \\
\hline
\end{tabular}

Means followed by same letter do not significantly differ $(\mathrm{p}<0.05$, Tukey's test). Value in parenthesis followed by \pm is standard deviation $(\mathrm{n}=3)$.

Table 3. The nutrient contents in the organic fertilizersused in this study.

\begin{tabular}{cccc}
\hline Organic fertilizer & $\mathrm{TC}(\mathrm{mg} / \mathrm{kg})$ & $\mathrm{TN}(\mathrm{mg} / \mathrm{kg})$ & $\mathrm{C} / \mathrm{N}$ ratio \\
\hline Cow manure & $199,500^{\mathrm{b}}( \pm 20,560)$ & $11,580^{\mathrm{c}}( \pm 940)$ & $17^{\mathrm{a}}( \pm 0.5)$ \\
Chicken manure & $240,900^{\mathrm{b}}( \pm 19,300)$ & $35,410^{\mathrm{b}}( \pm 2630)$ & $7^{\mathrm{b}}( \pm 0.1)$ \\
Soybean meal & $446,800^{\mathrm{a}}( \pm 12,870)$ & $76,970^{\mathrm{a}}( \pm 1490)$ & $6^{\mathrm{b}}( \pm 0.2)$
\end{tabular}

Means followed by same letter do not significantly differ $(\mathrm{p}<0.05$, Tukey's test). Value in parenthesis followed by \pm is standard deviation $(n=3)$.

phosphorus (TP), total potassium (TK), total bacterial biomass, $\mathrm{N}$ circulation activity, and $\mathrm{P}$ circulation activity. The TC was analyzed using a TOC analyzer (Model: SSM-5000A, Shimadzu, Kyoto, Japan). The TN, TP, and TK were analyzed by extracting soil samples using the Kjeldahl digestion method followed by analysis using the indophenol blue method, molybdenum blue method, and atomic absorption spectrophotometry, respectively [20].

The total bacterial biomass in soil was estimated by quantification of environmental DNA (eDNA) extracted by using the slow-stirring method [21]. The extracted eDNA was quantified based on the intensity of the eDNA bands after electrophoresis on agarose gel using Kodak 1D 3.6 Image Analysis Software (Kodak, CT, USA). The bacterial biomass in the soil was estimated by using the equation $Y=1.70 \times 10^{8} X\left(\mathrm{r}^{2}=0.96\right)$, where $Y$ and $X$ are the bacterial biomass $\mathrm{g}^{-1}$ soil and the amount of eDNA, respectively.

The $\mathrm{N}$ circulation activity was analyzed based on the values of ammonium oxidation activity, nitrite oxidation activity, and the total bacterial biomass [20]. The bacterial biomass of $6.0 \times 10^{8}$ cells. $\mathrm{g}^{-1}$ was defined as 100 points. Using the scores of bacterial biomass, ammonium oxidation rate, and nitrite oxidation rate, a radar chart was constructed, and the relative area of the inner triangle was expressed as the $\mathrm{N}$ circulation activity. 
The area of the triangle in the radar chart was calculated as follows:

$$
\text { Area }=\frac{(a \times b)+(b \times c)+(c \times a)}{4} \times \frac{\sqrt{3}}{100}
$$

where, $a, b$, and $c$ denote scores of bacterial biomass, ammonium oxidation rate, and nitrite oxidation rate, respectively. The area of the outer triangle was calculated by the maximum values and the inner one was by the measured scores.

Nitrogen circulation activity was analyzed by calculating the relative area of inner triangle as follows:

$$
N \text { circulation activity }=\frac{\text { Area of the inner triangle }}{\text { Area of the outer triangle }} \times 100
$$

Similarly, the $P$ circulation activity was estimated using the methods of Horii et al. [22] by analyzing the rate of mineralization of organic $\mathrm{P}$ from the substrate (sodium phytate) during an incubation period of 3 days at $25^{\circ} \mathrm{C}$.

Soil texture was analyzed with the hydrometer method [23] using a Bouyoucos Hydrometer (type 152H). The $\mathrm{pH}$ and electrical conductivity (EC) were analyzed using a $\mathrm{pH}$ meter (LAQUA F-72, Horiba, Kyoto, Japan) and an EC meter (5LE1-408, Kenis, Hyogo, Japan), respectively, in a 1:2.5 soil-to-water suspension $(\mathrm{w} / \mathrm{v})$.

\subsection{Analysis of Tomato Fruit Quality}

A composite sample of at least three tomato fruits from each treatment were mixed using a grinder. The fruit suspension was kept in a freezer $\left(-20^{\circ} \mathrm{C}\right)$ until lycopene, glutamic acid, antioxidants, sugar, and acid analysis.

\subsubsection{Lycopene Analysis}

Lycopene in tomato was estimated following the procedures of Fish et al. [24]. A tomato fruit suspension (about $0.5 \mathrm{~g}$ ) was placed in a $50-\mathrm{mL}$ brown glass vial. Subsequently, $5 \mathrm{~mL}$ of $0.05 \%$ but ylated hydroxytoluene (w/v in acetone), $5 \mathrm{~mL}$ of $95 \%$ ethanol and $10 \mathrm{~mL}$ of hexane were added to the vial. The vial was shaken reciprocally at $150 \mathrm{rpm}$ for $15 \mathrm{~min}$ under cool conditions. After shaking, the mixture was allowed to stand for $5 \mathrm{~min}$ at room temperature. The upper layer (hexane layer) was taken for spectrophotometric analysis $(503 \mathrm{~nm})$. The lycopene concentration in the fruit suspension was calculated as follows based on the sample weight:

$$
\text { Lycopene concentration }(\mathrm{mg} / 100 \mathrm{~g})=\frac{\text { Absorbance at } 503 \mathrm{~nm} \times 536.9}{17.2 \times 10 \times \text { sample weight }(\mathrm{g})}
$$

where, 17.2 is molar extinction coefficient of lycopene in hexane and 536.9 is molecular weight of lycopene.

\subsubsection{Glutamic Acid Content and Polygalacturonase Activity}

Glutamic acid in tomato fruit suspension was determined using a Yamasa L-glutamic acid measurement kit II (Cosmo Bio Co. Ltd., Tokyo, Japan) accord- 
ing to the manufacturer's instructions. Polygalacturonase activity was analyzed according to the procedures of [25] [26].

\subsubsection{Water-Soluble Antioxidants Concentration}

The water-soluble antioxidants concentration was estimated spectrophotometrically using the molybdenum blue method. The diluted tomato fruit suspension was combined with $1 \mathrm{~mL}$ of ammonium molybdate solution $(0.6 \mathrm{M}$ sulfuric acid, $30 \mathrm{mM}$ disodium phosphate, and $4 \mathrm{~m}$ Mhexaammoniumheptamolybdate, in water) and incubated at $90^{\circ} \mathrm{C}$ for $1 \mathrm{~h}$. The absorbance of the solution was then measured at $695 \mathrm{~nm}$. A standard curve was prepared against the known concentrations of ascorbic acid.

\subsubsection{Sugar and Acid Contents}

The sugar content (Brix) was analyzed using a DBX-55 refractometer (Atago, Tokyo, Japan). The acid content was determined by titrating the fruit extract with $0.1 \mathrm{M}$ sodium hydroxide until $\mathrm{pH} 4.1$ was reached based on $\mathrm{pH}$ meter readings (LAQUA F-72, Horiba, Kyoto, Japan). Since about $80 \%$ of the total organic acid is citric acid in tomato [27], acid content was calculated in terms of citric acid following the procedures of Garner et al. [28].

\subsection{Statistical Analysis}

All analyses were carried out in 3 replicates. Statistically significant differences were identified using ANOVA/Tukey's test. Temporal differences in bacterial biomass, $\mathrm{N}$ circulation activity, and $\mathrm{P}$ circulation activity in 2015 experiment were compared using t-test.

\section{Results}

\subsection{Effect of Soil Conditions on Growth and Yield of Tomato}

To investigate suitable organic soil conditions for tomato cultivation, the effects of soil conditions on tomato growth and yield were investigated. Soil conditions (TC, TN, and $\mathrm{C} / \mathrm{N}$ ratio), microbial biomass in soil, and tomato yield in organic (Fields A, B, D, and E) and chemical fields (Fields C and F) are shown in Table 4. The average tomato yields in organic fields ranged between 1290 to 5380 $\mathrm{kg} / 0.1$ ha. Among the four organic fields, the yields in Fields A and B were significantly lower than those in Fields $\mathrm{D}$ and E. Compared with the average tomato yield cultivated in Shiga prefecture, Japan $(2470 \mathrm{~kg} / 0.1 \mathrm{ha})$, the yields in the organic fields (Fields A and B) in 2013 were $48 \%$ to $36 \%$ lower, whereas yield of tomatoes cultivated in the Fields D and E in 2014 were 118 and 45\% higher, respectively. The bacterial biomass in organic fields was $\geq 10.2 \times 10^{8}$ cells/g.

Although the environmental condition is an important factor for plant growth, microbial biomass and nutrient cycling activities are mainly affected by $\mathrm{TC}, \mathrm{TN}$, and $\mathrm{C} / \mathrm{N}$ ratio [20]. The role of microorganisms and nutrient cycling activity are crucial for the plant growth in organic farming systems. Therefore, 
Table 4. Bacterial biomass and tomato yield in the experimental fields of 2013 and 2014. Bacterial biomass was analyzed one week after fertilizer application.

\begin{tabular}{ccccc}
\hline Year & $\begin{array}{c}\text { Experimental } \\
\text { field }\end{array}$ & $\begin{array}{c}\text { Bacterial biomass } \\
\left(\times 10^{8} \text { cells/g }\right)\end{array}$ & $\begin{array}{c}\text { Yield } \\
(\mathrm{kg} / 0.1 \mathrm{ha})\end{array}$ & $\begin{array}{c}{ }^{*} \text { Relative yield } \\
(\%)\end{array}$ \\
\hline 2013 & A & $10.2^{\mathrm{bc}}( \pm 0.36)$ & $1580^{\mathrm{de}}( \pm 62)$ & 64 \\
& B & $11.5^{\mathrm{b}}( \pm 0.87)$ & $1290^{\mathrm{e}}( \pm 110)$ & 52 \\
& C & $7.4^{\mathrm{c}}( \pm 0.30)$ & $1750^{\mathrm{d}}( \pm 56)$ & 71 \\
& D & $15.3^{\mathrm{a}}( \pm 2.07)$ & $3580^{\mathrm{b}}( \pm 130)$ & 145 \\
& E & $12.6^{\mathrm{ab}}( \pm 2.14)$ & $5380^{\mathrm{a}}( \pm 160)$ & 218 \\
& F & $13.7^{\mathrm{ab}}( \pm 0.98)$ & $2500^{\mathrm{c}}( \pm 69)$ & 101 \\
\hline
\end{tabular}

Means followed by same letter do not significantly differ ( $\mathrm{p}<0.05$, Tukey's test). Value in parenthesis followed by \pm is standard deviation $(n=3)$. ${ }^{\star}$ Relative yield in each field was calculated with reference to the average tomato yield of $2470 \mathrm{~kg} / 0.1$ ha in Shiga prefecture from 2009 to 2013 (source: database of Ministry of Agriculture, Forestry and Fisheries, Japan (available at: http://www.maff.go.jp)).

we analyzed the yield of tomato grown in 2 years in relation to TC, TN, and $\mathrm{C} / \mathrm{N}$ ratio.

The tomato yield was highly affected by the soil conditions (TC, TN, and C/N ratio) in the organic fields. The yield was significantly highest in Field E having TC $36,000 \mathrm{mg} / \mathrm{kg}$, TN $1900 \mathrm{mg} / \mathrm{kg}$, and C/N ratio 19 , but significantly low yield was observed in the fields A and B having high levels TC (57,000 to 58,000 $\mathrm{mg} / \mathrm{kg}$ ) and TN (2800 to $4300 \mathrm{mg} / \mathrm{kg}$ ). Although the tomato yields were low in Fields A and B, the shoot yields (stem and leaf, without fruits) were higher than those in the chemically fertilized field (data not shown). These results suggest that TN contents in Fields A and B were too high for tomato cultivation. From these cultivation results, TC around 36,000 $\mathrm{mg} / \mathrm{kg}$, TN around $1900 \mathrm{mg} / \mathrm{kg}$, and $\mathrm{C} / \mathrm{N}$ ratio about 20 seem to be suitable organic soil conditions for high tomato yield.

\subsection{Reproducibility of Soil Conditions for Tomato Cultivation}

To examine the reproducibility of the most suitable soil conditions for tomato cultivation observed in the previous experiment (i.e., TC $36,000 \mathrm{mg} / \mathrm{kg}$ and $\mathrm{C} / \mathrm{N}$ ratio 20), three organic fields with similar TC but different $\mathrm{C} / \mathrm{N}$ ratio were prepared. The bacterial biomass and tomato yield in the three organic fields (Fields G, H, and I) are shown in Table 5. In the fields, bacterial biomass was $\geq 9.0 \times 10^{8}$ cells/g. The tomato yields were significantly higher in Field H (5960 $\mathrm{kg} / 0.1 \mathrm{ha}$ ) and Field I ( $5540 \mathrm{~kg} / 0.1 \mathrm{ha}$ ) compared to that in Field G (3170 $\mathrm{kg} / 0.1 \mathrm{ha}$ ), but the yield in Field $\mathrm{G}$ was still higher than the regional average yield $(2470 \mathrm{~kg} / 0.1 \mathrm{ha})$. In addition, the values of $\mathrm{TC}, \mathrm{TN}$, and $\mathrm{C} / \mathrm{N}$ ratio in Fields $\mathrm{H}$ and I were similar to those in the high yielding field (Field $\mathrm{E}$ ) of previous experiment (Table 2). These results confirm that a high tomato yield can be achieved by maintaining the soil conditions similar to those of Fields $\mathrm{H}$ and I. 
Table 5. Bacterial biomass and yield of tomato in the experimental fields of 2015. Bacterial biomass was analyzed one week after organic fertilizer application.

\begin{tabular}{ccccc}
\hline Year & $\begin{array}{c}\text { Experimental } \\
\text { field }\end{array}$ & $\begin{array}{c}\text { Bacterial biomass } \\
\left(\times 10^{8} \text { cells/g }\right)\end{array}$ & $\begin{array}{c}\text { Yield } \\
(\mathrm{kg} / 0.1 \mathrm{ha})\end{array}$ & $\begin{array}{c}{ }^{*} \text { Relative yield } \\
(\%)\end{array}$ \\
\hline \multirow{2}{*}{2015} & $\mathrm{G}$ & $11.0^{\mathrm{ab}}( \pm 0.44)$ & $3170^{\mathrm{b}}( \pm 210)$ & 128 \\
& $\mathrm{H}$ & $9.0^{\mathrm{b}}( \pm 1.10)$ & $5960^{\mathrm{a}}( \pm 390)$ & 241 \\
& $\mathrm{I}$ & $12.0^{\mathrm{a}}( \pm 0.92)$ & $5540^{\mathrm{a}}( \pm 430)$ & 224 \\
\hline
\end{tabular}

Means followed by same letter do not significantly differ ( $\mathrm{p}<0.05$, Tukey's test). Value in parenthesis followed by \pm is standard deviation $(\mathrm{n}=3)$. ${ }^{*}$ Relative yield in each field was calculated with reference to the average tomato yield of $2470 \mathrm{~kg} / 0.1$ ha in Shiga prefecture from 2009 to 2013 (source: database of Ministry of Agriculture, Forestry and Fisheries, Japan (available at: http://www.maff.go.jp)).

\subsection{Relationship among Yield and Quality of Tomato and Nutrient Circulation Activities in Soil}

The quality of tomato was also analyzed in the three organic fields in 2015 (Fields G, H, and I) and compared with the yield (Figure 2). Lycopene and glutamic acid contents in Fields $\mathrm{H}$ and I (soil TN $1600 \mathrm{mg} / \mathrm{kg}$ and $1700 \mathrm{mg} / \mathrm{kg}$ ) were significantly higher than those in Field H (soil TN $1000 \mathrm{mg} / \mathrm{kg}$ ). In contrast, no significant differences in antioxidant content, polygalacturonase activity, and sugar content were observed among the three fields, but the acid content in Field G was slightly lower than in Field I. Therefore, the soil conditions of Fields $\mathrm{H}$ and I would improve both yield and quality in tomato cultivation.

Bacterial biomass and nutrient circulation activities were examined in the three organic fields of 2015 (Figure 3). The bacterial biomass in the fields ranged from $9.0 \times 10^{8}$ to $1.4 \times 10^{9}$ cells/g-soil. No relationship between bacterial biomass and tomato yield was observed, but the $\mathrm{N}$ and $\mathrm{P}$ circulation activities were significantly higher in Fields $\mathrm{H}$ and I (higher tomato yields) than those in Field G (lower tomato yield). The results suggest that high levels of $\mathrm{N}$ and $\mathrm{P}$ circulation activities in soil contributes for the enhancement of tomato yield and quality.

\subsection{Analysis of Suitable Soil Conditions for Tomato Cultivation under an Organic Farming System}

To find the suitable soil conditions for tomato cultivation under an organic farming system, soil properties in the three experimental fields of 2015 (Fields G, $\mathrm{H}$, and I) were analyzed (Table 6). In the high-yielding fields (Fields $\mathrm{H}$ and I), available nitrogen (ammonium and nitrate) and electrical conductivity (EC) were significantly higher than those in the low yielding field (Field G). The tomato quality parameters (lycopene, glutamic acid, and acid contents) were also higher in Fields $\mathrm{H}$ and I. Based on a series of the experiments, for tomato cultivation in the organic farming system, TC and TN in soil should be enhanced by organic materials but higher $\mathrm{C} / \mathrm{N}$ ratio seems to reduce the tomato yield. Therefore, the following soil properties were identified as suitable conditions for tomato cultivation under an organic farming system: TC of 30,000 - 36,000 mg/kg, TN of 1600 to $1900 \mathrm{mg} / \mathrm{kg}, \mathrm{C} / \mathrm{N}$ ratio of $18-21$, TP of $1000-1500 \mathrm{mg} / \mathrm{kg}$, and TK of $3000-4000 \mathrm{mg} / \mathrm{kg}$. 


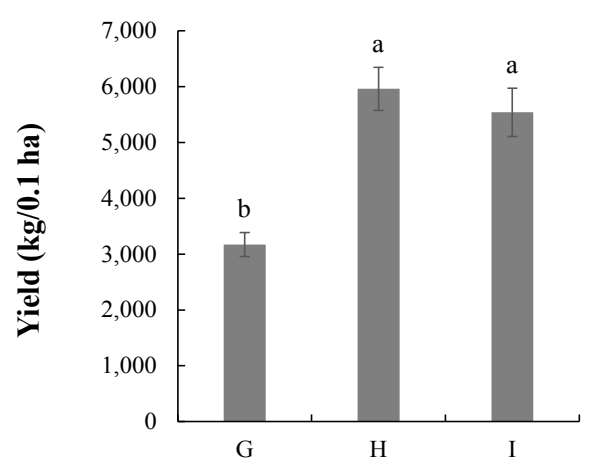

Field
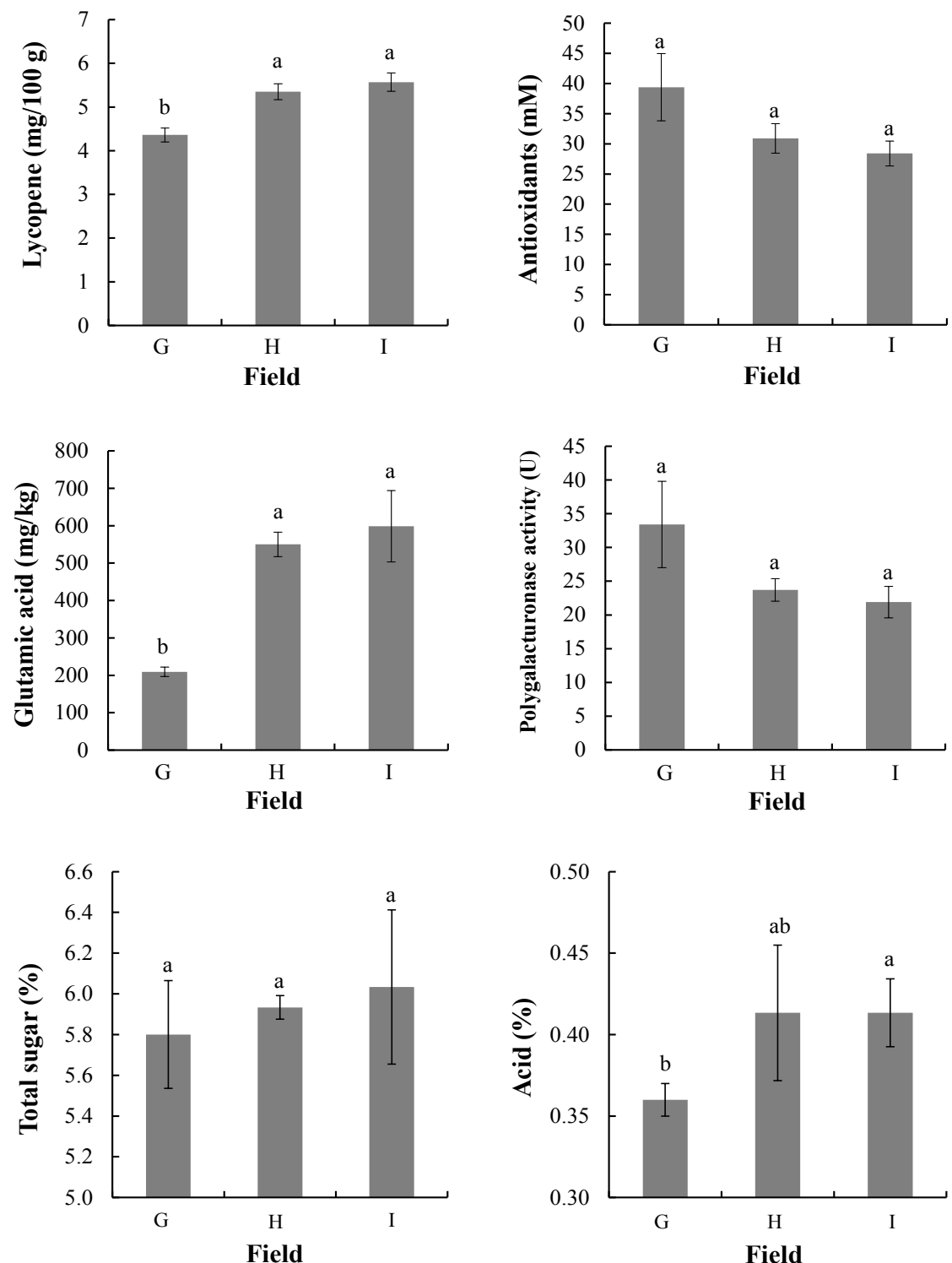

Figure 2. Yield and quality of tomato in the three experimental fields of 2015. Yield (kg/0.1 ha), lycopene ( $\mathrm{mg} / 100 \mathrm{~g})$, antioxidants $(\mathrm{mM})$, glutamic acid $(\mathrm{mg} / \mathrm{kg})$, polygalacturonase activity (U), total sugar (\%), and acid (\%) of Fields G, H, and I are shown. Each value is an average of three replications. Error bars denote the standard deviation. Values with same letter do not significantly differ ( $\mathrm{p}<0.05$, Tukey's test). 


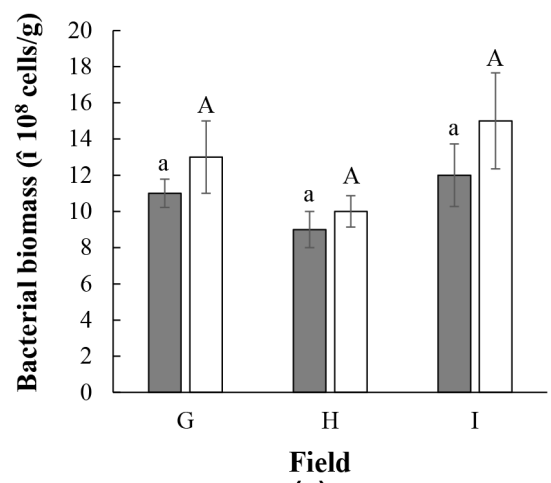

(a)

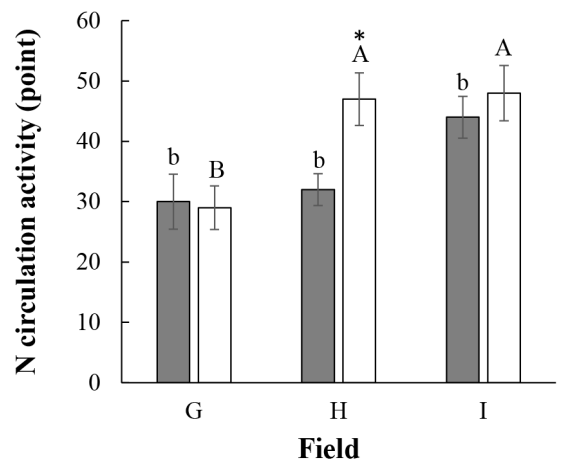

(b)

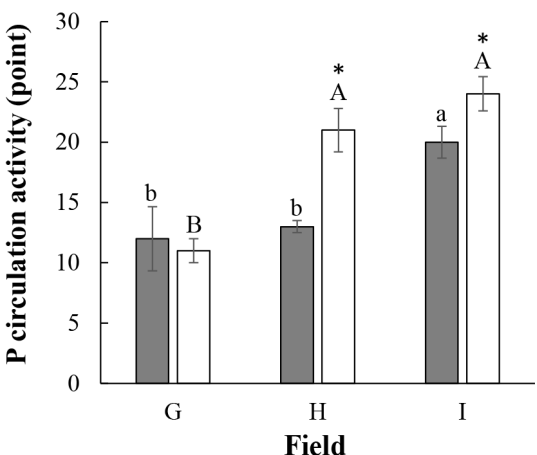

(c)

Figure 3. Microbiological properties of soil in three experimental fields of 2015. Bacterial biomass $\left(\times 10^{8}\right.$ cells/g) (a), $\mathrm{N}$ circulation activity (point) (b), and $\mathrm{P}$ circulation activity (point) (c) of Fields G, H, and I are shown. Bars filled with solid gray ( $\square$ ) and with ho-

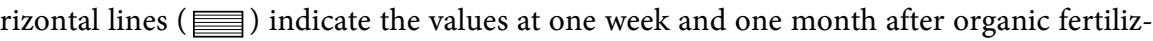
er application, respectively. Values with same letter in an observation period (lowercase for one week and uppercase for one month) do not significantly differ ( $\mathrm{p}<0.05$, Tukey's test). Asterisk $\left(^{*}\right)$ indicates significant difference between two observation periods in the same field $(\mathrm{p}<0.05, \mathrm{t}$-test).

\section{Discussion}

Recent reports show that only $1 \%$ of agricultural fields in the world are cultivated under an organic farming system [8]. This is typically because the yields under organic farming are unstable or because a successful organic cultivation requires several years of experience [11] [13] [14] [15]. In the current study, we investigated the suitable soil conditions for tomato cultivation under an organic farming system.

Soil microorganisms play several beneficial roles in cultivated land such as decomposition of organic materials, nitrification, and $\mathrm{P}$ mineralization. Therefore, microorganisms are important parameters for soil fertility. In our previous study, we showed that $\mathrm{TC}, \mathrm{TN}$, and $\mathrm{C} / \mathrm{N}$ ratio are closely related to the bacterial biomass and nutrient cycling activities in soil [20] [29] Enhancement of microorganisms and their activities are more important under organic systems than under conventional systems, because microorganisms help to supply nutrients to plants by decomposing the added organic materials. Properly controlled TC, TN 
Table 6. Relationship between soil properties and tomato yield in the experimental fields of 2015. Soil properties analyzed after one week of organic fertilizer application are shown.

\begin{tabular}{|c|c|c|c|}
\hline Soil property and tomato yield & Field G & Field $\mathrm{H}$ & Field I \\
\hline \multicolumn{4}{|l|}{ Total nutrient amount and ratio } \\
\hline $\mathrm{TC}(\mathrm{mg} / \mathrm{kg})$ & $31,000^{\mathrm{a}}( \pm 2000)$ & $33,000^{\mathrm{a}}( \pm 1730)$ & $30,000^{\mathrm{a}}( \pm 1730)$ \\
\hline $\mathrm{TN}(\mathrm{mg} / \mathrm{kg})$ & $1000^{\mathrm{b}}( \pm 170)$ & $1600^{a}( \pm 100)$ & $1700^{\mathrm{a}}( \pm 87)$ \\
\hline $\mathrm{C} / \mathrm{N}$ ratio & $31^{\mathrm{a}}( \pm 4.2)$ & $21^{\mathrm{b}}( \pm 1.6)$ & $18^{\mathrm{b}}( \pm 1.9)$ \\
\hline $\mathrm{TP}(\mathrm{mg} / \mathrm{kg})$ & $900^{\mathrm{b}}( \pm 36)$ & $1100^{\mathrm{b}}( \pm 44)$ & $1400^{\mathrm{a}}( \pm 140)$ \\
\hline $\mathrm{TK}(\mathrm{mg} / \mathrm{kg})$ & $3450^{\mathrm{a}}( \pm 53)$ & $3500^{\mathrm{a}}( \pm 92)$ & $3700^{\mathrm{a}}( \pm 230)$ \\
\hline \multicolumn{4}{|l|}{ Soluble nutrient } \\
\hline $\mathrm{NH}_{4}^{+}-\mathrm{N}(\mathrm{mg} / \mathrm{kg})$ & $45^{\mathrm{b}}( \pm 6.6)$ & $83^{\mathrm{a}}( \pm 8.2)$ & $63^{\mathrm{ab}}( \pm 7.0)$ \\
\hline $\mathrm{NO}_{3}^{-}-\mathrm{N}(\mathrm{mg} / \mathrm{kg})$ & $8^{c}( \pm 2.0)$ & $41^{\mathrm{b}}( \pm 4.4)$ & $60^{\mathrm{a}}( \pm 6.6)$ \\
\hline Soluble P (mg/kg) & $14^{\mathrm{a}}( \pm 3.6)$ & $21^{\mathrm{a}}( \pm 6.6)$ & $23^{\mathrm{a}}( \pm 4.6)$ \\
\hline Soluble K (mg/kg) & $46^{\mathrm{a}}( \pm 4.7)$ & $46^{\mathrm{a}}( \pm 8.5)$ & $29^{\mathrm{b}}( \pm 6.2)$ \\
\hline \multicolumn{4}{|l|}{$\mathrm{pH}$ and $\mathrm{EC}$} \\
\hline pH (1:2.5 soil-water; w/v) & $5.9^{\mathrm{a}}( \pm 0.15)$ & $5.8^{\mathrm{a}}( \pm 0.05)$ & $5.7^{\mathrm{a}}( \pm 0.10)$ \\
\hline $\mathrm{EC}(\mathrm{ds} / \mathrm{m})$ & $0.1^{\mathrm{b}}( \pm 0.02)$ & $0.4^{\mathrm{a}}( \pm 0.10)$ & $0.4^{\mathrm{a}}( \pm 0.04)$ \\
\hline Tomato yield (kg/0.1 ha) & $3170^{\mathrm{b}}( \pm 240)$ & $5960^{\mathrm{a}}( \pm 390)$ & $5540^{\mathrm{a}}( \pm 430)$ \\
\hline
\end{tabular}

Means followed by same letter do not significantly differ $(\mathrm{p}<0.05$, Tukey's test). Value in parenthesis followed by \pm is standard deviation $(\mathrm{n}=3)$.

and $\mathrm{C} / \mathrm{N}$ ratios result in a high level bacterial biomass and enhanced $\mathrm{N}$ and $\mathrm{P}$ circulation activities.

Generally, the yields under organic systems are either unstable or lower compared to those in the conventional systems [11] [13] [14] [15]. Nitrogen availability is the most important in limiting yield of tomato under organic farming systems [30]. A previous study demonstrated that high level of tomato yields under organic farming systems than that under conventional systems was associated to the high nitrogen mineralization rate and higher microbial diversity in soils under organic systems [31]. In this study, we found that properly controlled $\mathrm{TC}, \mathrm{TN}$, and $\mathrm{C} / \mathrm{N}$ ratio and high levels of $\mathrm{N}$ circulation activity and $\mathrm{P}$ circulation activity resulted into higher tomato yield in the organic fields compared to the chemically fertilized fields. Therefore, enhancement of the number and activities of microorganisms by maintenance of the soil condition (especially TC, TN, and $\mathrm{C} / \mathrm{N}$ ratio) seem necessary for achieving high yield of tomato from organic farming systems.

Organic crop products are typically considered to be of high quality [9] [32]. In general, quality and quantity are oppositely related in crop products obtained under conventional farming systems [33]. In this study, lycopene, glutamic acid, and acid contents in tomato fruit seemed to be enhanced in the high-yielding organic fields. Lycopene is a major antioxidant component [34], and glutamic 
acid, sugar, and acidity are the major taste indicators in tomato [35]. Enhancement of sugar and organic acid contents in organically produced tomatoes have also been reported previously [36]. Therefore, appropriate soil conditions in organic systems not only enhance the yield of tomato but also can improve the quality.

A suitable organic soil condition of tomato would be also effective for other vegetable fruits. In this point, the amount of $\mathrm{TN}$ and the balance of $\mathrm{C} / \mathrm{N}$ in soil are most important, because higher $\mathrm{C} / \mathrm{N}$ ratio inhibits reproduction and enhances vegetative growth (Table 4). However, crop production could be increased only after the organic soil enhances activities of microorganisms maintaining appropriate nutrients for plants.

\section{Conclusion}

In this experiment, a suitable soil condition for increasing the yield of tomatoes in an organic farming system was determined as TC of $30,000-36,000 \mathrm{mg} / \mathrm{kg}$, $\mathrm{TN}$ of $1600-1900 \mathrm{mg} / \mathrm{kg}$, and a C/N ratio of $18-21$. The quality of tomato also seems to be changed by soil environmental condition.

\section{Acknowledgements}

We would like to acknowledge the support provided by Dr. Chikayoshi Kitamura (Kinki Agri-Hightech, Kyoto, Japan), Mr. Hitoshi Kawabata (JA Ominchi, Moriyama, Shiga, Japan), and Mr. Kiyokazu Morita (Yasu, Shiga, Japan) during the field experiment. The authors also acknowledge the CCP program.

\section{Conflict of Interest}

The authors declare no conflicts of interest in this paper.

\section{References}

[1] Food and Agricultural Organization of the United Nations (2014) FAOSTAT: Crop Data, 2014. http://www.fao.org/faostat/en/\#data/QC

[2] Duke, J.A. and Ayensu, E.S. (1985) Medicinal Plants of China. Reference Publications, Inc.

[3] Sánchez-Moreno, C., Plaza, L., de Ancos, B. and Cano, M.P. (2006) Nutritional Characterisation of Commercial Traditional Pasteurised Tomato Juices: Carotenoids, Vitamin C and Radical-Scavenging Capacity. Food Chemistry, 98, 749-756. https://doi.org/10.1016/j.foodchem.2005.07.015

[4] Kucuk, O. (2001) Phase II Randomized Clinical Trial of Lycopene Supplementation before Radical Prostatectomy. Cancer Epidemiology, Biomarkers and Prevention, 10, 861-868.

[5] Piccardi, N. and Manissier, P. (2009) Nutrition and Nutritional Supplementation: Impact on Skin Health and Beauty. Dermato-Endocrinology, 1, 271-274. https://doi.org/10.4161/derm.1.5.9706

[6] Giovannucci, E., Ascherio, A., Rimm, E.B., Stampfer, M.J., Colditz, G.A. and Willett, W.C. (1995) Intake of Carotenoids and Retino in Relation to Risk of Prostate Can- 
cer. Journal of the National Cancer Institute, 87, 1767-1776.

https://doi.org/10.1093/jnci/87.23.1767

[7] Easdown, W. and Kalb, T. (2004) Antioxidant Capacities and Daily Antioxidant Intake from Vegetables Consumed in Taiwan. AVRDC Progress Report, Asian Vegetable Research and Development Center, Shanhua.

[8] FiBL and IFOAM (2017) The World of Organic Agriculture Statistics and Emerging Trends, 2017. Research Institute of Organic Agriculture FiBL and IFOAM-Organics International. http://www.organic-world.net/yearbook/yearbook-2017.html

[9] Woese, K., Lange, D., Boess, C. and Bogl, K.W. (1997) A Comparison of Organically and Conventionally Grown Foods-Results of a Review of the Relevant Literature. Journal of the Science of Food and Agriculture, 74, 281-293. https://doi.org/10.1002/(SICI)1097-0010(199707)74:3<281::AID-JSFA794>3.0.CO;2 $\underline{-Z}$

[10] Chassy, A.W., Bui, L., Renaud, E.N., Van Horn, M. and Mitchell, A.E. (2006) Three-Year Comparison of the Content of Antioxidant Microconstituents and Several Quality Characteristics in Organic and Conventionally Managed Tomatoes and Bell Peppers. Journal of Agricultural and Food Chemistry, 54, 8244-8252. https://doi.org/10.1021/jf060950p

[11] Mitchell, A.E., Hong, Y.J., Koh, E., Barrett, D.M., Bryant, D.E., Denison, R.F. and Kaffka, S. (2007) Ten-Year Comparison of the Influence of Organic and Conventional Crop Management Practices on the Content of Flavonoids in Tomatoes. Journal of Agricultural and Food Chemistry, 55, 6154-6159. https://doi.org/10.1021/jf070344+

[12] Vallverdú-Queralt, A., Jáuregui, O., Medina-Remón, A. and Lamuela-Raventos, R.M. (2012) Evaluation of a Method to Characterize the Phenolic Profile of Organic and Conventional Tomatoes. Journal of Agricultural and Food Chemistry, 60, 3373-3380. https://doi.org/10.1021/jf204702f

[13] Mäder, P., Fliessbach, A., Dubois, D., Gunst, L., Fried, P. and Niggli, U. (2002) Soil Fertility and Biodiversity in Organic Farming. Science, 296, 1694-1697. https://doi.org/10.1126/science.1071148

[14] de Ponti, T., Rijk, B. and van Ittersum, M.K. (2012) The Crop Yield Gap between Organic and Conventional Agriculture. Agricultural Systems, 108, 1-9. https://doi.org/10.1016/j.agsy.2011.12.004

[15] Seufert, V., Ramankutty, N. and Foley, J.A. (2012) Comparing the Yields of Organic and Conventional Agriculture. Nature, 485, 229-232. https://doi.org/10.1038/nature11069

[16] Singh, J.S., Pandey, V.C. and Singh, D.P. (2011) Efficient Soil Microorganisms: A New Dimension for Sustainable Agriculture and Environmental Development. Agriculture, Ecosystems and Environment, 140, 339-353. https://doi.org/10.1016/j.agee.2011.01.017

[17] Chen, M., Xu, P., Zeng, G., Yang, C., Huang, D. and Zhang, J. (2015) Bioremediation of Soils Contaminated with Polycyclic Aromatic Hydrocarbons, Petroleum, Pesticides, Chlorophenols and Heavy Metals by Composting: Applications, Microbes and Future Research Needs. Biotechnology Advances, 33, 745-755. https://doi.org/10.1016/j.biotechadv.2015.05.003

[18] Adhikari, D., Perwira, I.Y., Araki, K.S. and Kubo, M. (2016) Stimulation of Soil Microorganisms in Pesticide-Contaminated Soil Using Organic Materials. AIMS Bioengineering, 3, 379-388. https://doi.org/10.3934/bioeng.2016.3.379

[19] Franzluebbers, A.J. (2002) Soil Organic Matter Stratification Ratio as an Indicator of 
Soil Quality. Soil and Tillage Research, 66, 95-106. https://doi.org/10.1016/S0167-1987(02)00018-1

[20] Adhikari, D., Kai, T., Mukai, M., Araki, K.S. and Kubo, M. (2014) A New Proposal for a Soil Fertility Index (SOFIX) for Organic Agriculture and Development of a SOFIX Database for Agricultural Fields. Current Topics in Biotechnology, 8, 81-91.

[21] Aoshima, H., Kimura, A., Shibutani, A., Okada, C., Matsumiya, Y. and Kubo, M. (2006) Evaluation of Soil Bacterial Biomass Using Environmental DNA Extracted by Slow-Stirring Method. Applied Microbiology and Biotechnology, 71, 875-880. https://doi.org/10.1007/s00253-005-0245-x

[22] Horii, S., Matsuno, T., Tagomori, J., Mukai, M., Adhikari, D. and Kobo, M. (2013) Isolation and Identification of Phytate-Degrading Bacteria and Their Contribution to Phytate Mineralization in Soil. The Journal of General and Applied Microbiology, 59, 353-360. https://doi.org/10.2323/jgam.59.353

[23] Bouyoucus, G.J. (1962) Hydrometer Method for Making Particle Analysis of Soil. Agronomy Journal, 54, 464-465.

https://doi.org/10.2134/agronj1962.00021962005400050028x

[24] Fish, W.W., Perkins-Veazie, P. and Collins, J.K. (2002) A Quantitative Assay for Lycopene That Utilizes Reduced Volumes of Organic Solvents. Journal of Food Composition and Analysis, 15, 309-317. https://doi.org/10.1006/jfca.2002.1069

[25] Takehana, H., Shibuya, T., Nakagawa, H. and Ogura, N. (1977) Purification and Some Properties of Endo-Polygalacturonase from Tomato Pericarp. Technical Bulletin of Faculty of Horticulture No. 25, Chiba University, Chiba. (In Japanese)

[26] Tucker, G.A., Robertson, N.G. and Grierson, D. (1981) The Conversion of Tomato-Fruit Polygalacturonase Isoenzyme 2 into Isoenzyme 1 in Vitro. European Jour nal of Biochemistry, 115, 87-90. https://doi.org/10.1111/j.1432-1033.1981.tb06201.x

[27] Bradley, D.B. (1960) The Separation of Organic and Inorganic Acid Anions in Filtered Tomato Puree by Partition Chromatography. Journal of Agricultural and Food Chemistry, 8, 232-234. https://doi.org/10.1021/jf60109a020

[28] Garner, D., Crisosto, C.H., Wiley, P. and Crisosto, G.M. (2003) Measurement of pH and Titratable Acidity. http://fruitandnuteducation.ucdavis.edu/files/162035.pdf

[29] Araki, K.S., Perwira, I.Y., Adhikari, D. and Kubo, M. (2016) Comparison of Soil Properties between Upland and Paddy Fields Based on the Soil Fertility Index (SOFIX). Current Trends in Microbiology, 10, 85-94.

[30] Clark, M.S., Horwath, W.R., Shennan, C., Scow, K.M., Lantni, W.T. and Ferris, H. (1999) Nitrogen, Weeds and Water as Yield-Limiting Factors in Conventional, Low-Input, and Organic Tomato Systems. Agriculture, Ecosystems and Environment, 73, 257-270. https://doi.org/10.1016/S0167-8809(99)00057-2

[31] Drinkwater, L.E., Letourneau, D.K., Workneh, F.A.C.H., Van Bruggen, A.H.C. and Shennan, C. (1995) Fundamental Differences between Conventional and Organic Tomato Agroecosystems in California. Ecological Applications, 5, 1098-1112. https://doi.org/10.2307/2269357

[32] Worthington, V. (2001) Nutritional Quality of Organic versus Conventional Fruits, Vegetables, and Grains. Journal of Alternative and Complementary Medicine, 7, 161-173. https://doi.org/10.1089/107555301750164244

[33] Caliman, F.R.B., da Silva, D.J.H., Stringheta, P.C., Fontes, P.C.R., Moreira, G.R. and Mattedi, A.P. (2008) Relation between Plant Yield and Fruit Quality Characteristics of Tomato. Bioscience Journal, 24, 46-52.

[34] Agarwal, S. and Rao, A.V. (2000) Tomato Lycopene and Its Role in Human Health 
and Chronic Diseases. Canadian Medical Association Journal, 163, 739-744.

[35] Oruna-Concha, M.J., Methven, L., Blumenthal, H., Young, C. and Mottram, D.S. (2007) Differences in Glutamic Acid and 5'-Ribonucleotide Contents between Flesh and Pulp of Tomatoes and the Relationship with Umami Taste. Journal of Agricultural and Food Chemistry, 55, 5776-5780. https://doi.org/10.1021/jf070791p

[36] Xu, H.L., Wang, R. and Mridha, M.A.U. (2001) Effects of Organic Fertilizers and a Microbial Inoculant on Leaf Photosynthesis and Fruit Yield and Quality of Tomato Plants. Journal of Crop Production, 3, 173-182.

https://doi.org/10.1300/J144v03n01_15 